\title{
Protecting the Prehospital Professional First Aid Teams from Airborne Viral Particles in the Case of Out-of-Hospital Pediatric Cardiac Arrest during the COVID-19 Pandemic
}

\author{
Sabine Lemoine, MD;® Frederique Briche, MD; Daniel Jost, MD; Bertrand Prunet, MD, PhD Prof
}

Paris Fire Brigade, Medical Emergency Department, Paris, France

\author{
Correspondence: \\ Sabine Lemoine, MD \\ Paris Fire Brigade, Medical Emergency \\ Department \\ 1 place Jules Renard 75017 Paris France \\ E-mail: sabine.lemoine@pompiersparis.fr
}

Conflicts of interest/funding: none

Received: April 16, 2020

Accepted: May 7, 2020

\section{doi:10.1017/S1049023X2000062X}

(C) The Author(s), 2020. Published by Cambridge University Press on behalf of World Association for Disaster and Emergency Medicine. This is an Open Access article, distributed under the terms of the Creative Commons Attribution licence (http://creativecommons.org/licenses/by/ 4.0/), which permits unrestricted re-use, distribution, and reproduction in any medium, provided the original work is properly cited.
Lemoine S, Briche F, Jost D, Prunet B. Protecting the prehospital professional first aid teams from airborne viral particles in the case of out-of-hospital pediatric cardiac arrest during the COVID-19 pandemic. Prehosp Disaster Med. 2020;35(4):467.

To the Editor,

The pediatric 2019 novel coronavirus disease (COVID-19) cases report mostly asymptomatic or mild infections, with a better prognosis than in adults. ${ }^{1,2}$ Any pediatric victim who dies from COVID-19 has a significant media impact. These pediatric COVID-19 cardiac arrests occur mostly in intra-hospital settings. To datewe have not found any publication on the prehospital management of COVID-19 pediatric out-of-hospital cardiac arrest (OHCA) by Basic Life Support (BLS) teams (personal systematic review).

In Paris, France, the Fire Brigade Prehospital Rescue System treats approximately 50 pediatric OHCA per year. From March 20, 2020 to April 7, 2020, two children benefited from prehospital cardiopulmonary resuscitation by a BLS team with an unknown etiology.

During the pandemic, in the case of pediatric OHCA whose etiology is definitely not a COVID-19 infection, children should be considered in all cases as potential carriers of COVID-19, and therefore as contaminants as a symptomatic adult, particularly from nasopharyngeal and stool excretion. ${ }^{1}$

We are focusing on raising awareness among prehospital teams working on pediatric OHCAs about the need to systematically protect themselves regardless of the cause of pediatric OHCAand routinely wear personal protective equipment (gloves, filtering face piece [FFP2] respirators, goggles, and long-sleeved gown), especially since there are still uncertainties about the spread of airborne viral particles during resuscitation procedures such as chest compressions, defibrillation, insufflation maneuvers, tracheal intubation, and oral and pharyngeal aspirations. ${ }^{3,4}$

The International Liaison Committee will reach a consensus on the science of the balance between therapeutic benefit and risk of contamination for each of these procedures, also for pediatric cases.

\section{References}

1. Hagman SFH. COVID-19 in children: more than meets the eye. Travel Med Infect Dis. 2020; epub ahead of print.

2. Dong Y, Mo X, Hu Y, et al. Epidemiological characteristics of 2,143 pediatric patients with 2019 coronavirus disease in China. Pediatrics. 2020; epub pre-publication ahead of print.

3. Tran K, Cimon K, Severn M, Pessoa-Silva CL, Conly J. Aerosol generating procedures and risk of transmission of acute respiratory infections to healthcare workers: a systematic review. PLoS One. 2012;7:e35797.

4. Mahase E, Kmietowicz Z. Covid-19: doctors are told not to perform CPR on patients in cardiac arrest. BMJ. 2020;368: $\mathrm{m} 1282$. 